\title{
FEATURES OF OPTIMIZATION OF INCREASING THE EFFICIENCY OF AN AUTONOMOUS PHOTO THERMAL INSTALLATION FOR RURAL REGIONS
}

\author{
Muminov R. ${ }^{1,2}$, Tursunov M. ${ }^{1,2}$, Yuldoshev I. ${ }^{1 *}$, Sabirov H. ${ }^{1,2}$, Kholov U. ${ }^{2}$, Akhtamov T. ${ }^{2}$ \\ ${ }^{1}$ Tashkent State Technical University named after Islam Karimov Uzbekistan, 100095, Tashkent, st. \\ Universitetskaya, 2 \\ ${ }^{2}$ Physical-Technical Institute of SPA "Physics-Sun" of Uz AS, 2B, Chingiz Aytmatov str., 100084, Tashkent, \\ Uzbekistan
}

\begin{abstract}
The paper considers experimental results on the development of a photovoltaic battery of a new design with increased efficiency and power with a new heat collector based on cellular polycarbonate, which leads to complete uniform thermal contact with the back surface of the photovoltaic battery. It is shown that the use of materials with a high reflection coefficient in the side plane of solar radiation reflection, increasing the accuracy of the operational guidance node to the sun using an upgraded support structure that allows orientation to the sun in two planes, reduces the loss of solar radiation energy. It is possible to control the capacity of the heat collector, which ensures the reliability of obtaining parameters, increases power, and ensures uniformity of the temperature of the rear surface of the PVB, which increases the efficiency of the installation.
\end{abstract}

\section{Introduction}

It is known that the main sources of energy in isolated regions, remote from more developed territories adjacent to district centers, due to the decommissioning of the infrastructure of centralized sources of electric energy (power lines, transformer equipment, etc.), makes it advisable to use renewable energy sources in the future. First of all, photovoltaic power sources that generate electrical energy.

It is known that rural regions located far from regional centers have undeveloped production forces. In such isolated rural households, electricity is mainly used for household and household needs. The average monthly consumption of electricity for one family does not exceed 70-100 kWh, i.e. $1200 \mathrm{~kW}$ per year. Another problem in such rural areas is the provision of water, including hot water to meet household and household needs and create comfort when washing, washing dishes and showering. In the absence or shortage of coal, gas, fuel oil and firewood in rural regions, it is necessary to use the method of heating water with electric water heaters $(\mathrm{EWH})$ of the "Ariston" type to obtain hot water. With the current shortage of electricity, the use of EWH is problematic. The use of PVB traditional designs in summer season in hot climates in rural areas for generating electrical energy is not efficient due to

\footnotetext{
Corresponding author: isroil.yuldoshev@tdtu.uz
}

significant reduction in power from PVS under the influence of temperature and air pollution (dust the surface of PVB). The availability of running water in isolated rural areas is also scarce in the summer, and the population uses water from artesian wells and wells for their needs using electricity using gasoline or diesel units. In the case of isolated rural areas, Autonomous photovoltaic stations (APVS) should be created with increased efficiency and a reliable power supply system. When using APVS in countries with a hot climate in southern latitudes (in particular in Uzbekistan), there are specific factors that differ from the conditions of use in other countries. These factors are extreme temperature conditions that lead to a decrease in the efficiency of the APVS conversion and relatively high dust content of the atmospheric air. Both factors work simultaneously, especially in the summer season, from April to October. High dust content of the air is practically valid all year round. In this case, in rural regions of the Republic, APVS should be equipped with solar thermal (PTB) batteries that provide both electric energy and warm water to rural households.

\section{Methods and materials.}

We have developed different variants of thermal collectors to increase the efficiency of photo thermal batteries (PTB) [1-7]. The efficiency of the collector 
part of PTB, is determined by the efficiency of heat exchange between the rear surface of the PVB and into contact with her material thermal collector. The main reason for the low efficiency of the collector part is the small contact area with the rear surface of the PVB. Along with this, the high weight, cost of material, and complex manufacturing technology of the collector part of the PTB using metal structures makes it uncompetitive with the PVB of traditional construction. The possibility of using combined installations based on photo thermal and hybrid systems is analyzed in [8].

The paper [9] presents the results of a study of the possibility of using cellular polycarbonate as a thermal collector of PTB, the manufacturing technology and properties of PTB with such a collector depending on various climatic factors. In addition, two solar radiation reflection planes are additionally placed on the front side of the photovoltaic battery. The total area of the side planes of solar radiation reflection is equal to the area of the photovoltaic part of the battery. The angle of inclination to the solar radiation of the reflecting planes is changed and adjusted. The optimal angle of inclination of the side reflecting surfaces to the Sun is determined by the maximum value of the shortcircuit current of the photovoltaic battery. Reflecting planes, outside of working hours (at night), are used as a cover (protection) to prevent contamination of the surface of the photovoltaic battery. The density of solar radiation using reflective surfaces can be increased to $1200-1300 \mathrm{~W} / \mathrm{m} 2$, which does not lead to a deviation of the regularity of changes in the linearity of the short-circuit current from the density of solar radiation incident on the surface of a PVB based on crystalline silicon. That is, the sequential resistance of silicon solar cells does not change, and the conversion efficiency of solar energy is maintained with increasing solar radiation density.

\section{Results}

This paper presents the results of design development and research of installation parameters with a new photo thermal battery. The electrical power of the unit is twice as high as the previous variants [9]. The installation has an upgraded support structure that allows orientation to the sun in two planes. Photo the thermal battery is based on the PVB with a power of $340 \mathrm{~W}$. To increase the accuracy of measuring the parameters of the PTB installation, the design allows changing the position of the PVB in two coordinates and accurately orienting it in relation to the sun. For fig. 1 and 2 show the structure of a photovoltaic and photo thermal battery for comparison.

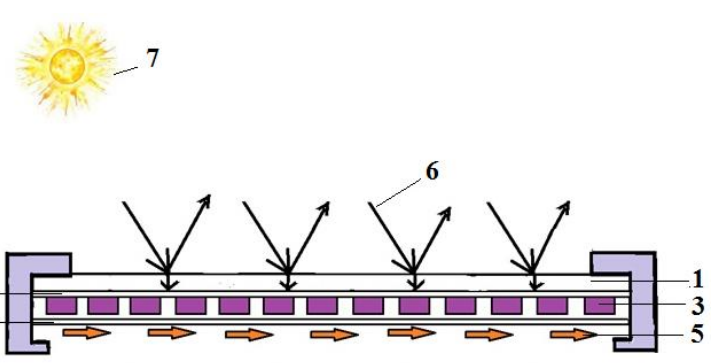

Fig. 1. The structure of the photovoltaic battery of traditional design.

1-frontal glass, 2-sealant, 3-solar cell, 4-sealant, 5-loss of heat by convective heat exchange, 6 -solar radiation, 7 -sun.

Solar radiation falling on the surface of the PVB is partially reflected, and the main part is absorbed by the silicon structure (more than 90\%). However, due to the limited conversion efficiency $(\sim 20 \%)$, the nonparticipating part of the radiation is absorbed by the rear metal contact and increases the temperature of the solar cell structure. Heat loss on the back side of the photovoltaic battery occurs only by convective heat exchange with the environment (Fig.1). At wind speeds of up to 5-10 $\mathrm{m} \mathrm{sec}$, effective heat exchange between the rear surface of the PVB and the environment is provided at lower ambient temperatures. In [10], it was shown that if the ambient temperature is more than $30^{\circ} \mathrm{C}$, the change in the temperature of the PVB with an increase in wind speed is insignificant $(20 \%)$ and for the effective operation of the PVB, it must be cooled by other methods.

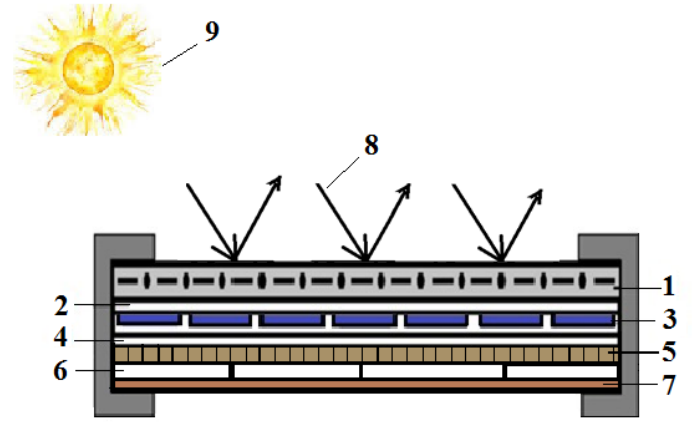

Fig. 2. The structure of the photo thermal battery of the proposed design.

1-frontal glass, 2-sealant, 3-solar cell,4-sealant, 5- cellular polycarbonate, 6- heat insulation layer, 7-rear cover, 8-solar radiation, 9-sun.

For fig. 2 shows the structure of the photo thermal battery of the developed design. One of the main advantages of this design is the strict isolation of the thermal part (5,6,7 parts) from the influence of the environment. The technology of manufacturing a heat collector is given in [9]. To reduce heat losses along the perimeter, the collector is covered with a heat- 
insulating layer and reflective aluminum foil over the entire surface of the back side. A thick layer of heatinsulating coating on the back of the PTB is fixed with a sheet of polymer material $2 \mathrm{~mm}$ thick. Heat leakage through the front protective glass is insignificant in the multilayer structure and continuity of incident solar radiation and its absorption by the solar cell structure. In addition, the surface temperature of the front protective glass does not differ much from the temperature of the back side of the structure (by $10-14{ }^{\circ} \mathrm{C}$ ). Therefore, in such a system, the heat transfer from the rear surface of the PVB to the water increases significantly and the recovery time of the idling voltage decreases.

For rice. 3 shows the installation based on a photo thermal battery during measurement in full-scale conditions at the Heliopolygon of the Physicstechnical institute. To increase the conversion efficiency of solar radiation, as in the case [9] two side reflection planes are made. Measurements of the photo thermal battery parameters were carried out according to the previously developed method [9].

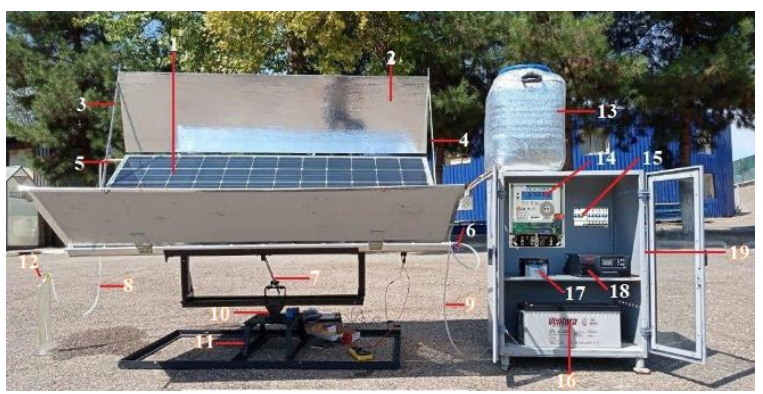

Fig. 3. Photo thermal installation based on a photo thermal battery of a new design.

1-solar cell, 2- side reflecting plane, 3,4-rod is an approximate reflecting plane, 5 - hot water valve, 6 -hot cold valve, 7-rod orientation on the vertical axis, 8,9- water supply hoses, 10-node orientation on the horizontal axis,

11- installation grounds, 12 - beaker for measuring the volume of hot water, 13-cold water tank, 14- electric meter,

15- knife switch, 16- accumulator, 17-controller, 18-invertor, 19- rack for appliances.

The Feb parameters were measured alternately with the heat collector switched off and without the use of a side reflecting plane. Then, the measurements were made by pointing the side reflecting plane at the photovoltaic battery. At the end, a heat collector with cold water connection was used. Experiments on the measurement of photothermal installation was carried out on 22 July 2020, in terms of Physical-technical Institute of RPA "Physics-Sun" Academy of Sciences of Uzbekistan. Air temperature $36-38{ }^{\circ} \mathrm{C}$, humidity $26 \%$, wind speed $3-5 \mathrm{~m} / \mathrm{s}$ in clear weather, measurement time from 10 hours 30 minutes to 13 hours 30 minutes. The density of the solar radiation flux incident on the surface of the photovoltaic battery PTB was measured with a standard silicon solar cell and was $820-850 \mathrm{~W} / \mathrm{m} 2$ during the experiment. After completing the measurement of parameters in full-scale conditions of solar radiation, all additional operations, the front surface of the photovoltaic battery PTB is covered with side reflection planes ("cover") to prevent contamination of the surface (see Fig.4).

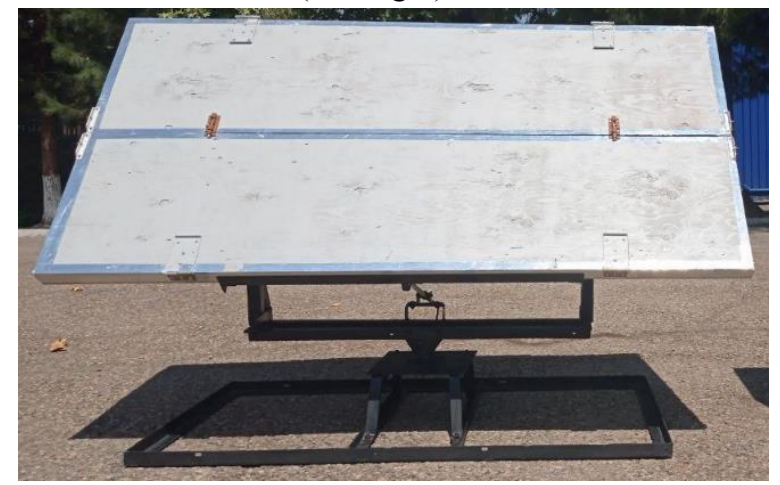

Fig. 4. Photo thermal battery after measuring parameters in natural conditions.

The use of a cover to protect the front surface of a photovoltaic PTB unit at night reduces the contamination of the PVB surface up to 4 times compared to the open surface[11-13]. For rice.5 shows the dependence of the no-load voltage on time for three modes: 1-using only the PVB, 2-using the PVB with side reflecting planes, and 3-using together the PVB, PTB and side reflecting planes. The course of the dependencies of the idle voltage on the time of day for all three cases of parameter measurement repeats the course of the dependencies for the previous setting [11]. 1-section of the course of the dependence of the no-load voltage of the PVB on time, the voltage decreases by $7.4 \mathrm{~V}$ (from 42.1 to 35.1) due to the heating of solar cells of the photovoltaic battery, which is $17.6 \%$. This reduction is 1.3 times less than for previous designs of a heat collector with a soft construction based on polymer tubes with "hydro protection" [9-10] with equal exposure time to solar radiation. With this rigid design of the heat collector based on cellular polycarbonate, air remains in parallel channels(in cellulars) with dimensions of 4x6x680 mm. Heating of the air occurs slowly, when solar radiation falls and is absorbed on the multilayer structure of the PVB in contact with the heat collector. This inertionaty is due to the complex process of heat exchange and the low value of the thermal conductivity of the air. For example, with further use of the PVB in this mode for 60 minutes(2-curve), the idling voltage reduction is more than $9.2 \mathrm{~V}(21.85 \%)$. 


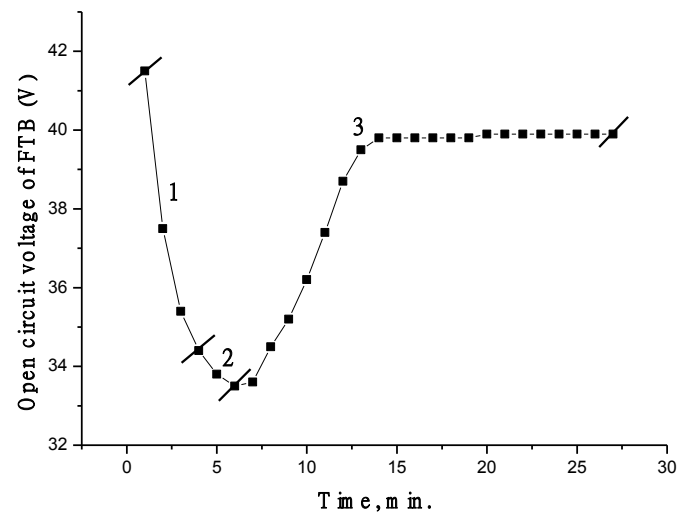

Fig. 5. Dependence of open circuit voltage on time at three modes of installation

1 - using only photovoltaic battery, 2 - using lateral reflective plane when pointing 3 - using all three blocks (PVB (Photovoltaic battery) + thermal collector + lateral reflective plane).

2-section (Fig.5.) connecting the side reflecting plane leads to a further decrease in the no-load voltage of the PTB due to an increase in the solar radiation flux on the surface of the photovoltaic battery by 1.3-1.4 times. Connecting the side reflecting planes leads to further heating of the structure within minutes (curve 2 of fig. 5) faster than in the case of using a "soft" heat collector. 3 - section, connection of cold water to the heat collector photo of the heat battery. Connecting cold water to the collector leads to an increase in the no-load voltage due to effective heat extraction from the back surface of the photovoltaic battery and its cooling. Then, due to the simultaneous action of high solar radiation density and heat transfer to water, the system reaches thermodynamic equilibrium and the operation mode (curve 3 ) of the heat collector is stabilized. The water temperature at the collector outlet was $62{ }^{\circ} \mathrm{C}$. At the same time, the capacity of hot water was 30 liters/hour. When the hot water temperature is reduced to $40{ }^{0} \mathrm{C}$, the water capacity increases to 50 liters/hour.

The time dependence of the short-circuit current is shown in Fig.6. The value of the short-circuit current according to Fig.6 are: 1 - for PVB at the beginning of $8.1 \mathrm{~A}$ and a further increase to $8.5 \mathrm{~A}$ (due to an increase in the solar radiation flux (from 10 hours to 11 hours), 2 - for PTB - up to 12 A (the increase in current is due to a change in the solar radiation power from $850 \mathrm{~W} / \mathrm{m} 2$ to $1100 \mathrm{~W} / \mathrm{m} 2$ during the measurement time), which is $41.1 \%$.

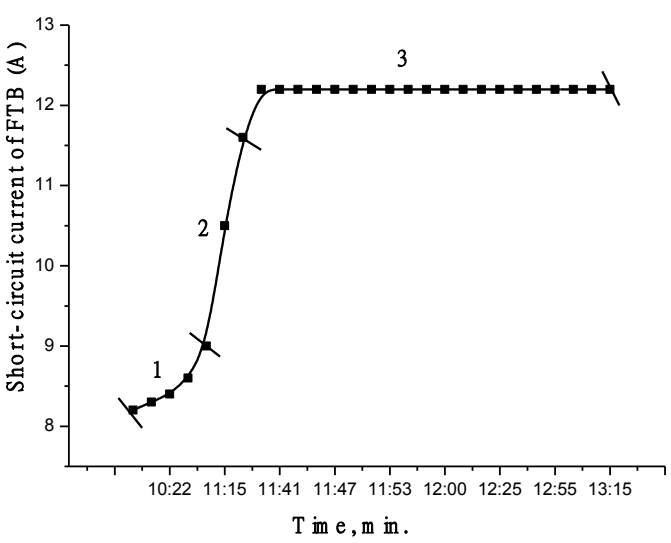

Fig. 6. Dependence of the short-circuit current on time in three modes of use of the installation.

1 - using only the photovoltaic battery, 2 - using the lateral reflective plane when pointing, 3 - using all three blocks (PVB (Photovoltaic battery) + heat collector + lateral reflective plane). The water temperature at the collector outletis $62{ }^{\circ} \mathrm{C}$.

Further, the value of the short-circuit current depends on the change in the solar radiation flux density on the surface of the photovoltaic battery. Further research shows that the short-circuit current up to 15-16 hours practically does not change. Figure 7 shows the dependence of the electrical power on the time when the unit is used in three modes.

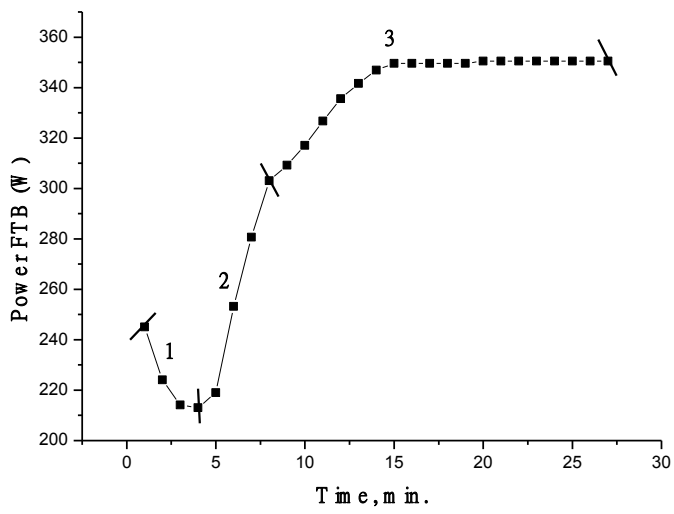

Fig. 7. Dependence of electrical power on time at three modes of using the installation.

1 - using only photovoltaic battery, 2 - using the lateral reflective plane when pointing, 3 - using all three blocks

(FEB (Photovoltaic battery) + heat collector + lateral reflective plane). Hot water temperature is $62{ }^{\circ} \mathrm{C}$.

\section{Discussion}

The dependence of electrical power on the time of day is shown for three modes of using a photo heat battery. In the mode of a photovoltaic battery (curve 1), the power of the PVB decreases: almost complete absorption of solar radiation occurs, with the exception of the reflected part of the protective glass. The limited conversion efficiency of solar cells (at the level of $20 \%$ ) leads to the fact that the unused 
part of solar energy in the volume of the crystal lattice accumulates closer to the rear surface of the solar cell structure (at the rear metal contacts) and increases the temperature of the crystal lattice. The limited thermal conductivity of the rear part of the PVB structure and the high temperature of the front protective glass (experimentally measured more than $57-60{ }^{0} \mathrm{C}$ ) do not allow heat dissipation through the front surface. In the 1 st section, the decrease in the electric power of the PVB was $40 \mathrm{~W}$, or $16.7 \%$. When the side reflecting plane (2-section) is deployed, the electric power increases due to an increase in the solar radiation flux by $41 \%$. The increase in electrical power is the result of two competing processes. An increase in the power of the solar radiation flux leads, first, to an increase in the generated electrical power (see Fig.7 curve 2) due to an increase in the short-circuit current of the photovoltaic battery (see Fig.6 curve). On the other hand, it leads to an increase in the temperature of the structure of PVB solar cells and a decrease in electrical power. Therefore, running water to the collector and cooling the back surface of the PVB additionally leads to an increase in electrical power due to an increase in the no-load voltage (see Fig.7 curve 3 ). The use of a side reflecting plane and a thermal collector as a whole increases the electrical power of the PTB from $210 \mathrm{~W}$ to $350 \mathrm{~W}$, by more than $70 \%$ (see Fig.7 curves 1,2 and 3) at the water temperature at the collector outlet $\mathrm{T} \sim 62^{\circ} \mathrm{C}$. When the water temperature at the collector outlet decreases by $20^{\circ} \mathrm{C}$, then the power increases by an additional $22-25 \mathrm{~W}$.

The mode of using the FTB installation with the side reflecting plane enabled may be different. To quickly fill the shortage of electrical energy, passing a large flow of cold water through the collector up to 60 liters/hour can get the necessary electrical power, up to 1.6-1.7 times more energy than the photovoltaic part of the battery. If you need to reserve a large amount of hot water with a temperature of up to 50 ${ }^{\circ} \mathrm{C}$ or more, you should reduce the flow of water passing through the heat collector to 20-30 liters/hour. When combined photo-thermal unit with electric heater (for example, type "Ariston"), in the case of the power supply of the heater from the photo-thermal battery can be obtained as electric energy and warm water at any time of the year [1416]. This makes it possible to create significant comfortable living conditions in rural households. To achieve practical results when combining PTB installations "Ariston" should conduct research on the use of PTB batteries in various options for switching heat collectors. The search for optimal modes when combining PTB installations with "Ariston", determining the necessary electrical power for the normal operation of an electric water heater in different seasons of the year is the subject of the following studies.

\section{Conclusion}

The proposed combined installation on the basis of an upgraded support structure and a photo of a new thermal battery with a heat collector made of cellular polycarbonate with side reflecting planes makes it possible to significantly increase the production of electric energy up to 1.6 times compared to a traditional PVB design, and provide year-round hot water to isolated rural households when used for household and household needs. In the future, it is planned to conduct research on the possibility of using a combined version of the installation with an electric water heater "Ariston" in the southern regions of the Republic for heating premises in the winter season.

\section{References}

[1] M.N. Tursunov, V.G. Dyskin, KH. Sobirov, B.M. Turdiev. Povyshenie ehffektivnosti raboty fototeplopreobrazovatel'noj ustanovki [Increasing the efficiency of the photo-heat converting installation]. Geliotekhnika, 2014 g. №4 p.84-86

[2] I.A. Yuldoshev, A.K. Saymbetov. Combined photo thermo converters solar energy with reflecting concentrators [Combined photo thermo converters solar energy with reflecting concentrators]. Proceedings of XII International Scientific Conference "Solid State Physics" 2014y. 25-27 June, p.217-219

[3] M.N. Tursunov, R.A. Muminov, O.F. Tukfatullin, I.A. Yuldoshevi EH.T. Abdullaev. Fototermo ehlektricheskie batarei naosnove kremnievykh solnechny khehlementov [Photothermoelectric batteries based on silicon solar cells]. Geliotekhnika, 2011, № 1, p.72-75

[4] J.S. Akhatov, I.AYuldashev, A.SHalimov. Experimental Investigations on PV-T collector under natural condition of Tashkent, Energy Procedia 39 (2013) Mexico. ISES Solar World Congress. p. 2327-2336

[5] M.N.Tursunov, R.A. Muminov, V.G. Dyskin and I.A. Yuldoshev. A Mobile Photothermal Convertor and Its Operating Characteristics, Appl.Solar Energy, 2013, №1, p. 23-27.

[6] B. Sandnes, J. Rekstad. A photovoltaic thermal $(P V / T)$ collector with a polymer absorber plate: experimental study and analytic model, Solar Energy. 2002. № 72 (1). p. 63-73.

[7] B.Hallmark, C.H.Hornung, D.Broady, C.PriceKuehne, M.R.Mackley. The application of plastic microcapillary films for fast transient micro-heat exchange, International Journal of Heat and MassTransfer, 2008, vol. 51, p. 5344-5358. 
[8] T.T. Chow. A review of photovoltaicthermal hybrid solar technology. Applied Energy 87 (2), 2010. p. 365-379.

[9] R.A. Muminov, M.N. Tursunov, X. Sabirov, U.Abdiev, B.A. Yuldoshev, Sh.N. Abilfayziev. Study of the Parameters of a Photo of a Thermal Battery with a cell Polycarbonate Collector, International Journal of Advanced Research in Science, Engineering and Technology, 2019 vol. 6, no. 12, p. 12018-12023.

[10] M.N. Tursunov, V.G. Dyskin, B.M. Turdiev, I.A. Yuldoshev. Vliyanie konvektivnogo teploobmena na temperature solnechnoj fotoehlektricheskoj batarei [Influence of convective heat transfer on the temperature of a solar photovoltaic battery]. Geliotekhnika, Tashkent, 2014. №4. p. 34-37.

[11] M. N. Tursunov, V. G. Dyskin, I.A. Yuldashev. Kriterij zagryazneniya poverkhnosti stekla fotoehlektricheskoj batarei [Criterion for contamination of photovoltaic battery glass surface]. Geliotekhnika. 2015, №2, p. 82-84

[12] M.N. Tursunov1, KH. Sabirov1, B.M. Turdiev². Povyshenie ehffektivnosti fototeplovykh batarej $s$ vozdushny mokhlazhdeniem, Mezhdunarodnaya konferentsiya [Improving the efficiency of air-cooled photo heat batteries]. «Fundamental'nye i prikladnye voprosy fiziki», 2017, p. 124-127.

[13] R. $A^{1}$. Muminov, M.N. Tursunov, $X^{1}$. Sabirov, E.T. Abdullaev, U. B ${ }^{2}$ Abdiev, B. A ${ }^{2}$. Yuldoshev, Sh. $\mathrm{N}^{2}$. Abilfayziev. Research methods for protecting the surface of photovoltaic batteries from pollution 1 Institute of Physics and Technology NPO "PhysicsSun", Republic of Uzbekistan 2 - Termez State University Republic of Uzbekistan, Asian Journal of Research № 1-3, 2020, p.3311-3315

[14] М.Н. Турсунов ${ }^{1}$, Б.М. Турдиев ${ }^{2}$, И.М. Комолов ${ }^{2}$. Исследование влияния температуры воды на параметры фото тепловой батареи [Investigation of the effect of water temperature on the parameters of a photo of a thermal battery]. International conference "Fundamental and applied problems of physics" 2017, p. 128-130.

[15] R.A ${ }^{2}$. Muminov, M. $\mathrm{N}^{2}$. Tursunov, $\mathrm{KH}^{2}$. Sabirov, S. K ${ }^{1}$. SHokuchkorov, M. $\mathrm{P}^{3}$. Pirimmatov, M. $\mathrm{N}^{3}$. Eshmurodova. Modernizatsiya fototeplovoj batarei dlya povysheniya ehffektivnosti ispol'zovaniya $v$ usloviya khzharkogo klimata [Modernization of the photo of the heat battery to increase the efficiency of use in hot climates]. Fizika poluprovodnikov i Mikroehlektronika, 2019, №, p58-64.

[16] R. A ${ }^{1}$. Muminov, M. $\mathrm{N}^{1}$. Tursunov, $\mathrm{KH}^{1}$. Sabirov, U. R ${ }^{1}$. KHolov, T. $\mathrm{Z}^{1}$. Akhtamov, M.N ${ }^{2}$. EHshmurodova. Kombinirovannaya ustanovkana osnove fototeplovoj batarei-ehlektrovodonagrevatel' dlya obespecheniya ehlektro ehnergiej $i$ vodoj sel'skie domokhozyajstva [Combined installation based on a photo thermal battery-electric water heater to provide rural households with electricity and water]. ZHurnal "Irrigatsiyai Melioratsiya” 2020, №2, p. 62 66. 